\title{
The Properties and Regulation of Functional Acetylcholine Receptors on Chick Ciliary Ganglion Neurons
}

\author{
Joseph F. Margiotta, Darwin K. Berg, and Vincent E. Dionne \\ Departments of Pharmacology and Biology, University of California, San Diego, La Jolla, California 92093
}

The properties of acetylcholine receptor (AChR) channels on chick ciliary ganglion neurons in culture were examined using patch-clamp recording techniques. Acetylcholine (ACh) was applied by rapid microperfusion. Whole-cell current noise analysis revealed a single class of functional receptors on the neurons. Dose-response studies indicated a $K_{d}$ of about $36 \mu \mathrm{M}$ and a Hill coefficient of 1.5-1.7, predicting $2 \mathrm{ACh}$ binding sites per receptor. Both fast and slow components of receptor desensitization were observed. Single-channel recordings from excised outside-out patches of soma membrane exposed to 2-5 $\mu \mathrm{M} A C h$ indicated a single-channel conductance of $40 \mathrm{pS}$, a reversal potential of $-9 \mathrm{mV}$, a mean open duration of $1 \mathrm{msec}$, and an opening probability of 0.34 . The kinetic behavior of the channels was provisionally described by a 3-closed, 1-open state model for receptor activation. In all of these properties, AChRs of ciliary ganglion neurons resemble those on skeletal muscle fibers.

Growing the neurons in an elevated $\mathrm{K}^{+}$concentration produced a 2-3-fold decrease in peak whole-cell currents induced by $\mathrm{ACh}$ under standard test conditions, without altering any of the single-channel properties described above. Neither changes in cholinesterase activity nor receptor distribution accounted for the decrease. Instead, calculations indicated that elevated $\mathrm{K}^{+}$reduced the $\mathrm{ACh}$ response by decreasing the number of functional AChRs on the neurons. No $\mathrm{K}^{+}$-dependent decrease is observed, however, in the number of total receptors on the neurons detected either by a monocional antibody specific for the receptor or by an $\alpha$-neurotoxin that binds to the receptor and blocks its function. Moreover, the number of receptors detected by the 2 probes is at least $\mathbf{1 0}$-fold greater than the calculated number of functional receptors. The findings suggest that only a small fraction of the AChRs on the neuronal surface is functional and that the cell can alter the ratio of functional and nonfunctional receptors in response to growth conditions.

Cellular mechanisms controlling the function, distribution, and number of nicotinic acetylcholine receptors (AChRs) on skeletal muscle fibers have been studied extensively (for reviews see Fambrough, 1979; Schuetze and Role, 1987). Nicotinic AChRs

\footnotetext{
Received Dec. 29, 1986; revised Apr. 9, 1987; accepted Apr. 23, 1987.

This work was supported by NIH Grants NS 15344 and NS 12601 . The authors thank Dannielle Pellegrin for preparing cultures, and Drs. M. Howard, R. Maue, A. Ribera, N. Spitzer, and J. H. Steinbach for helpful discussions and comments on the manuscript.

Correspondence should be addressed to Joseph F. Margiotta, Division of Pharmacology, M-036, University of California, San Diego, La Jolla, CA 92093.

Copyright (C) 1987 Society for Neuroscience $0270-6474 / 87 / 113612-11 \$ 02.00 / 0$
}

are also found in many areas of the nervous system, where they mediate synaptic transmission between neurons. Although initial studies indicated that neuronal AChRs share some of the basic functional properties of their counterparts on skeletal muscle fibers (Rang, 1981; Derkach et al., 1983; Ogden et al., 1984), significant immunological, pharmacological, and structural differences have also been reported (Patrick and Stallcup, 1977a, b; Carbonetto et al., 1978; Ascher et al., 1979; Boulter et al., 1986). Because of these differences, rules that govern the regulation of $\mathrm{AChR}$ function, number, and distribution in muscle may not apply to neurons. Information about neuronal $\mathrm{AChR}$ regulation has been limited both because newly developed recording techniques have not been commonly applied to neurons, and because suitable probes for neuronal AChRs have not been available.

Patch-clamp techniques can now be used to examine the functional properties of individual neuronal AChRs. In addition, 2 probes have recently been developed for identifying neuronal AChRs. The first probe is a monoclonal antibody, mAb 35, which recognizes the "main immunogenic region" of the $\mathrm{AChR}$ alpha subunit from muscle and electric organ and cross-reacts with a component on chick autonomic neurons having properties expected of a neuronal AChR (Jacob et al., 1984; Smith et al., 1985, 1986; Stollberg et al., 1986). The second probe is a snake $\alpha$-neurotoxin, Bgt 3.1, which reversibly blocks the AChR response of chick autonomic neurons (Ravdin and Berg, 1979; Margiotta and Berg, 1982) and binds to the same receptors recognized by $\mathrm{mAb} 35$ on ciliary ganglion neurons in culture (Halvorsen and Berg, 1987). As expected, changes in the number of AChRs detected by the probes on neurons in culture generally agree well with changes in the level of ACh response (Smith et al., 1986). In at least one instance, however, a substantial discrepancy exists: growth of chick ciliary ganglion neurons in elevated $\mathrm{K}^{+}$leads to a 3-4-fold reduction in the $\mathrm{ACh}$-induced voltage response (Smith et al., 1983), with no decline in the number of surface receptors measured either with mAb 35 or with Bgt 3.1 (Smith et al., 1986; Halvorsen and Berg, 1987).

The present studies were undertaken to determine the basis for this apparent discrepancy and to gather new information about the functional properties of individual AChR channels on the neurons. Two possible explanations for the discrepancy were considered: Either growth in elevated $\mathrm{K}^{+}$alters some aspect of receptor function, such as single-channel conductance, open time, or opening probability; or it alters the number of functional channels in the neuronal plasma membrane. The first possibility would imply that the properties of AChRs can be altered by the neurons. The second possibility would point to a heterogeneity of surface receptors, suggesting that only a fraction of the total 
surface receptors is functional. Moreover, it would suggest that the cell can alter the relative numbers of functional and nonfunctional receptors on its surface as a consequence of the growth conditions.

We report here results from patch-clamp experiments on chick ciliary ganglion neurons that confirm the earlier findings from current-clamp experiments (Smith et al., 1983) and indicate that growth in elevated $\mathrm{K}^{+}$produces a $2-3$-fold reduction in peak whole-cell currents induced by fast application of $\mathrm{ACh}$. The reduction does not reflect a change in $\mathrm{AChR}$ single-channel conductance, reversal potential, mean open duration, opening probability, affinity, Hill coefficient, or apparent rates of desensitization. The altered growth condition appears to cause a decrease in the number of functional AChRs on the neurons, as calculated from the limiting value of the whole-cell conductance, the single-channel conductance, and the channel opening probability. These findings, together with the fact that the number of functional receptors detected under all conditions is substantially lower than the number of surface receptors measured by mAb 35 or Bgt 3.1 binding, support the interpretation that only a small fraction of the surface receptors on the neurons are functional, and that the neuron can alter the size of that fraction. New information about the functional properties of the receptors from whole-cell and single-channel recording is also provided. A preliminary account of some of these findings has appeared previously (Margiotta et al., 1985).

\section{Materials and Methods}

Cell culture. Ciliary ganglia were dissected from $8 \mathrm{~d}$ chick embryos; the neurons were dissociated and plated on $15-\mathrm{mm}$-diameter glass coverslips precoated with a substratum of collagen and lysed fibroblasts (Nishi and Berg, 1979, 1981). Plastic $35 \mathrm{~mm}$ culture dishes, each containing 3 coated coverslips, received $1-2 \times 10^{4}$ neurons. Cultures were maintained in an atmosphere of $95 \%$ air and $5 \% \mathrm{CO}_{2}$ at $37^{\circ} \mathrm{C}$ and grown in Eagle's minimal essential medium $\left(5 \mathrm{mM} \mathrm{K}^{+}\right)$with $10 \%$ (vol/vol) heatinactivated horse serum, $50 \mathrm{U} / \mathrm{ml}$ penicillin, and $50 \mu \mathrm{g} / \mathrm{ml}$ streptomycin. The culture medium was supplemented either with embryonic chick eye extract ( $3 \% \mathrm{vol} / \mathrm{vol}$; "eye medium") or with $\mathrm{KCl}(25 \mathrm{~mm}$ final concentration) plus eye extract (" $\mathrm{K}^{+} /$eye medium") (Nishi and Berg, 1981). The neurons received fresh culture medium at $2-3 \mathrm{~d}$ intervals.

Data acquisition. Neurons were used for experiments after 5-8 d in culture, a time at which the somata range from 15 to $20 \mu \mathrm{m}$ in diameter and ACh scnsitivity is at a high and relatively constant level (Smith et al., 1983). Coverslip cultures were transferred to a microscope stage and the neurons examined at room temperature $\left(21-24^{\circ} \mathrm{C}\right)$ under Normarski optics at $500 \times$ magnification. In all experiments, the cultures were bathed in a recording solution (modified from Dichter and Fischbach, 1977) containing (in mM) $145.0 \mathrm{NaCl}, 5.4 \mathrm{CaCl}_{2}, 5.3 \mathrm{KCl}, 0.8 \mathrm{MgCl}_{2}$, 5.6 glucose, 5 HEPES ( $\mathrm{pH} 7.4$ ), and $1 \mathrm{mg} / \mathrm{ml} \mathrm{BSA}$.

Patch electrodes were fabricated either from Hematocrit tubing (VWR Scientific, San Francisco, CA) or from Corning 8161 tubing (Garner Glass Co., Claremont, CA). The electrodes were coated with Sylgard resin (Dow Corning, Midland, MI) to reduce capacitance (Hamill et al., 1981), polished, and filled with an "intracellular" solution containing (in $\mathrm{mM}$ ) $145.6 \mathrm{CsCl}, 1.2 \mathrm{CaCl}_{2}, 2.0 \mathrm{EGTA}, 15.4$ glucose, and $5.0 \mathrm{Na}$ HEPES (pH 7.3). Cesium was used as the principal intracellular cation to block $\mathrm{K}^{+}$currents. Elcctrode resistances of $2-4 \mathrm{M} \Omega$ werc used to minimize series resistance correction in whole-cell recordings.

ACh (Sigma, St. Louis, MO) dissolved in recording solution was applied by pressure ejection (2-10 psi) from perfusion pipettes ( $4-8 \mu \mathrm{m}$ tip diameters) positioned $10-15 \mu \mathrm{m}$ from the neuron soma or excised patch. Using similar pipette sizes and pressures, others have shown that pipette contents reach the cell surface in 100-300 msec (Fenwick et al., 1982) with little dilution (Choi and Fischbach, 1981). With perfusion pipettes filled with fast green, and pressures, tip sizes, and distances from soma all within the range of those used in ACh experiments, we confirmed that the dye cloud rapidly surrounds the soma and proximal neurites. For noise measurements, the ACh concentration employed was typically $10 \mu \mathrm{M}$, which gave a sustained response, measurable for both growth conditions, and caused little or no observable desensitization of the whole-cell response. For single-channel measurements the ACh concentration was either 2 or $5 \mu \mathrm{M}$. Standard methods were used to form high-resistance seals (2-50 G 2 ) on the ncuronal soma and to achieve the whole-cell and outside-out patch recording configurations (Hamill et al., 1981).

Since the neurons are relatively large and arborize in culture, we tested the ability of the patch-clamp circuit to control the soma membrane potential in the whole-cell recording mode. When a series of depolarizing voltage pulses was applied to a neuron bathed in normal recording solution, the first observed Na currents were typically activated late in the pulse and in an all-or-none fashion; this was characteristically associated with poor spatial control of membrane voltage. If, however, the Na-recording solution was pressure-applied locally to the soma of a neuron bathed in Na-free saline (e.g., MacDermott and Westbrook, 1986), Na currents activated and inactivated normally. ACh was applied in a manner identical to the perfusion of Na-recording solution. From these results, we conclude that the patch-clamp circuit adequately controls the membrane voltage of the soma and other portions of the neuron exposed to the perfusion cloud. Presumably the controlled membrane extends somewhat beyond this limit.

Membrane currents were recorded using either a laboratory-built patchclamp equipped with a capacity-compensation circuit and incorporating a 10 G $\Omega$ feedback resistor in the headstage (Dionne and Leibowitz, 1982), or an Axopatch-1 patch-clamp (Axon Instruments, Burlingame, CA) incorporating selectable feedback resistors of $500 \mathrm{M} \Omega$ and $50 \mathrm{G} \Omega$ and equipped with circuitry for capacity compensation. Our records were not electronically corrected for series-resistance errors. Typically, series-resistance values were less than $6 \mathrm{M} \Omega$, making the error in holdingpotential measurements, associated with even the largest uncompensated whole-cell ACh currents (ca. $1000 \mathrm{pA}$ ) no larger than $6 \mathrm{mV}$ (Hamill et al., 1981). Holding potentials were corrected for this small error, as required. Whole-cell and single-channel currents were low-pass filtered at 2-5 kHz using either an 8-or 4-pole Bessel filter. Current fluctuations induced by $\mathrm{ACh}$ were bandpass filtered between $1 \mathrm{~Hz}$ and $1 \mathrm{kH} /$ with a 4-pole Butterworth filter. Currents were digitally recorded, either at $500 \mu \mathrm{sec}$ intervals for whole-cell records or at $100 \mu \mathrm{sec}$ intervals for single-channel records, using a laboratory computer (SMS 1000, Scientific Micro Systems, Mountain View, CA) equipped with an LSI-11/ 73 central processor (Digital Equipment Corp., Maynard, MA). Background and $\mathrm{ACh}$-induced current fluctuations were recorded in succession from 64 data segments, each containing 256 sample points.

Intracellular current clamp recording methods, described previously (O'Lague et al., 1978; Smith et al., 1983; McEachern et al., 1985), were used in determining the time course of the $\mathrm{K}^{+}$effect on ACh sensitivity. Ciliary ganglion neurons were grown in eye medium for 3-7 d and then switched to $\mathrm{K}^{+} / \mathrm{eye}$ medium for $2-72 \mathrm{hr}$. Sensitivity was determined by measuring the change in input conductance caused by perfusion with $100 \mu \mathrm{M}$ ACh. Constant current pulses of $0.05-0.20 \mathrm{nA}$ amplitude and $50 \mathrm{msec}$ duration were applied to the neuron, and the resulting membrane hyperpolarizations were recorded before and during exposure to the agonist. The ACh-induced conductance was calculated as the difference between the maximum input conductance in the presence of agonist and the resting input conductance prior to its application (Smith et al., 1983).

Data analysis. To analyze records of whole-cell current fluctuations, power density spectra (Katz and Miledi, 1972) were calculated from the variance of the current fluctuations using a fast Fourier transform method (Anderson and Stevens, 1973). The ACh-induced power spectral difference was calculated from whole-cell currents recorded before and during ACh exposure. These power spectra were fit with a Lorentzian function having the form

$$
S(f)=S(0) /\left[1+\left(f / f_{\mathrm{c}}\right)^{2}\right]
$$

where $f$ is the frequency, $S(0)$ is the asymptotic limit of the power at $f=0$ (in $\mathrm{A}^{2} \mathrm{sec}$ ), and $f_{c}$ is the corner frequency at which $S\left(f_{\mathrm{c}}\right)=S(0) / 2$. Assuming that the ACh-induced current fluctuations arise from the rapid opening and closing of AChR channels (Anderson and Stevens, 1973), the apparent channel burst duration will be given by $\tau_{\mathrm{b}}=1 / 2 \pi f_{\mathrm{c}}$. The apparent single-channel conductance $\left(\gamma_{\mathrm{a}}\right)$ was also estimated from the spectra, using the relation

$$
\gamma_{\mathrm{a}}=\pi f_{\mathrm{c}} S(0) / 2 I\left(V_{\mathrm{h}}-V_{\mathrm{r}}\right),
$$

where $V_{\mathrm{h}}$ is the holding potential, $I$ is the mean ACh-induced current, 
A

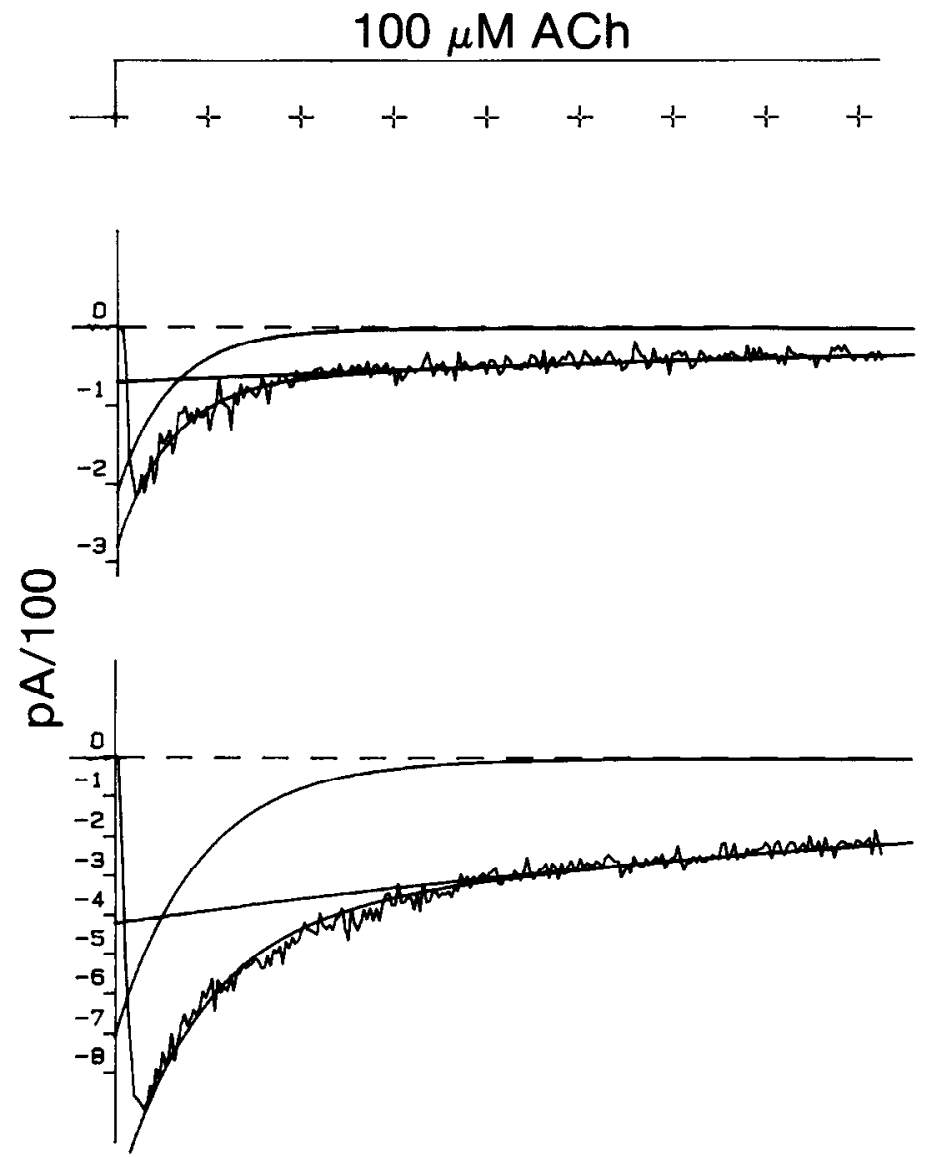

B

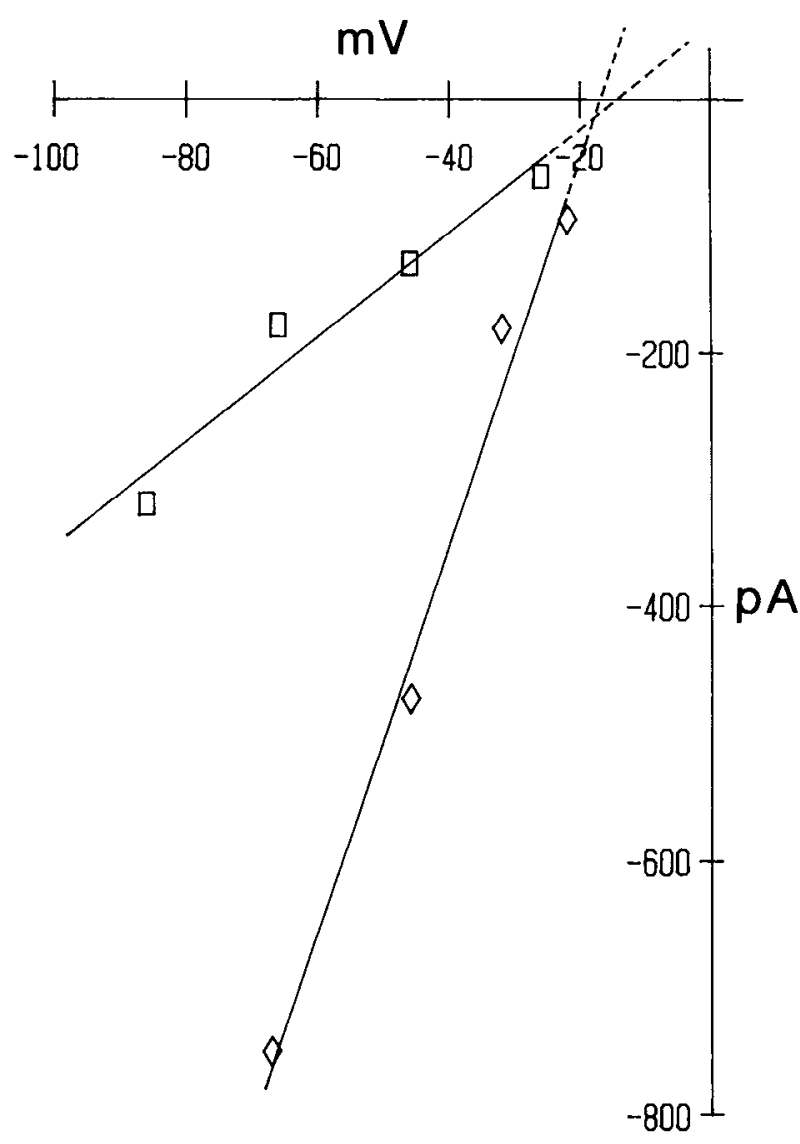

Figure 1. Whole-cell ACh responses. All recordings in this and subsequent figures were obtained in standard recording solution containing 5.3 mM K $\mathrm{K}^{+}$. A, ACh-induced current records obtained from 2 neurons grown in either $\mathrm{K}^{+}$/eye (upper record) or eye (lower record) medium for $7 \mathrm{~d}$. Both neurons depicted were held at $-65 \mathrm{mV}$ and exposed to $100 \mu \mathrm{M} \mathrm{ACh}$ for the duration of the recording, as indicated (top template; cursor separation, $1 \mathrm{sec})$. For each record, the solid curve fitted to the current relaxing from its peak value represents the sum of fast and slow exponential components of the current decay (solid curves above records). The maximal peak ACh currents extrapolated from the fits were $-270 \mathrm{pA}$ for the neuron grown in elevated $\mathrm{K}^{+}$and $-1050 \mathrm{pA}$ for the neuron grown in normal $\mathrm{K}^{+}$. The time constants of the fast $\left(\tau_{\mathrm{f}}\right)$ and slow $\left(\tau_{\mathrm{s}}\right)$ exponential decay processes were 0.7 and $12.7 \mathrm{sec}$, respectively, for the neuron grown in elevated $\mathrm{K}^{+}$, and 1.0 and $11.7 \mathrm{sec}$ for the neuron grown in normal $\mathrm{K}^{+} . B$, Whole-cell ACh current-voltage relationship. Peak extrapolated currents induced by $100 \mu \mathrm{M}$ ACh were obtained, as in $A$, at the indicated holding potentials from a neuron grown in $\mathrm{K}^{+} /$eye (squares) or eye (diamonds) medium. Whole-cell slope conductances obtained from the solid lines, fitted to the data by linear regression $(r>0.98)$, were $4.1 \mathrm{nS}$ and $15.2 \mathrm{nS}$; the dashed lines predict reversal of the whole-cell ACh currents at -14 and -17 $\mathrm{mV}$, respectively.

and $V_{\mathrm{r}}$ its reversal potential (Anderson and Stevens, 1973).

Single-channel currents from AChRs were recorded from outside-out patches and analyzed using methods similar to those of Dionne and Leibowitz (1982). Briefly, the amplitude, duration, and relative timing of events were detected and measured off-line using a computer-assisted search routine that allowed visual confirmation. Detection thresholds were near $50 \%$ of the fully open amplitude. Temporal resolution was set by the low-pass recording filter (typically $2-3 \mathrm{kHz},-3 \mathrm{~dB}$ ) and further constrained during analysis by ignoring both closed gaps and brief openings with durations of less than 2 sample intervals. Further details are provided in Results.

\section{Results}

\section{Whole-cell $A C h R$ currents}

Peak AChR currents. Measuring the peak amplitude of AChinduced whole-cell currents confirmed previous findings indicating a reduced voltage response for ciliary ganglion neurons grown in elevated $\mathrm{K}^{+}$concentrations (Smith et al., 1983). Responses from neurons raised in elevated and normal $\mathrm{K}^{+}$, each held at $-65 \mathrm{mV}$ and exposed to $100 \mu \mathrm{M} \mathrm{ACh}$ for the duration of the recording, are shown in Figure $1 A$. The peak $\mathrm{ACh}$-induced inward current was much smaller for the neuron grown in $\mathrm{K}^{+}$/ eye medium ( $-210 \mathrm{pA}$; Fig. $1 A$, upper record) than for the one grown in eye medium ( $-890 \mathrm{pA}$; Fig. $1 A$, lower record). In both cases, the current decayed in the continued presence of $\mathrm{ACh}$. The decay was biphasic and occurred more rapidly at higher agonist concentrations, presumably because of AChR desensitization (Katz and Thesleff, 1957; Sakmann et al., 1980). As shown by the solid lines associated with the records in Figure $1 A$, the time course of the decay in $\mathrm{ACh}$-induced current was well described by the sum of 2 exponential components, a dominant fast component and a smaller, slower component. With $100 \mu \mathrm{M} \mathrm{ACh}$, the time constants of the fast $\left(\tau_{\mathrm{f}}\right)$ and slow $\left(\tau_{s}\right)$ components were about 1 and $10 \mathrm{sec}$, values that did not differ between neurons grown in normal and in elevated $\mathrm{K}^{+}$. Knowing the rates of current decay for each trial, it was possible to estimate the maximal peak $\mathrm{ACh}$-induced current by extrapolating 


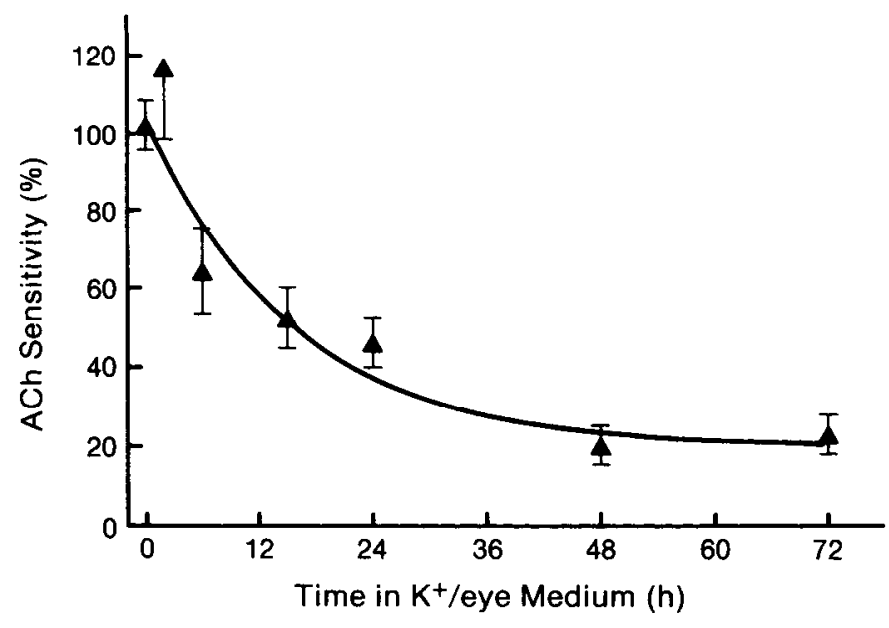

Figure 2. Time course of the reduction in ACh sensitivity produced by growth in elevated $\mathrm{K}^{+}$. Neurons were grown in eye medium for 3$7 \mathrm{~d}$, switched to $\mathrm{K}^{+} /$eye medium for the indicated durations, and then assayed for sensitivity to $100 \mu \mathrm{M}$ ACh using intracellular voltage recording techniques. ACh sensitivity is plotted as the percentage of the measured peak conductance increase assayed in control neurons from sister cultures grown in eye medium for an equivalenl duration. Each point represents the mean \pm SEM of 5-13 determinations from 2-3 separate culture platings. The curve was fitted to the data by a leastsquares nonlinear regression routine, which predicted a half-decay time to the equilibrium value $(20 \%)$ of about $11 \mathrm{hr}$.

back to the start of the ACh application, and thereby compensate for rapid desensitization. This extrapolation approach was employed for all whole-cell responses to estimate the maximal peak current ( -270 and $-1050 \mathrm{pA}$ for the neurons shown in Fig. 1). The use of extrapolated peak currents did not alter the general observation that $\mathrm{ACh}$-induced currents were reduced in neurons grown in clcvated $\mathrm{K}^{+}$.

The peak whole-cell conductance increase induced by $100 \mu \mathrm{M}$ $\mathrm{ACh}$ was assessed either by applying $\mathrm{ACh}$ to a neuron at different

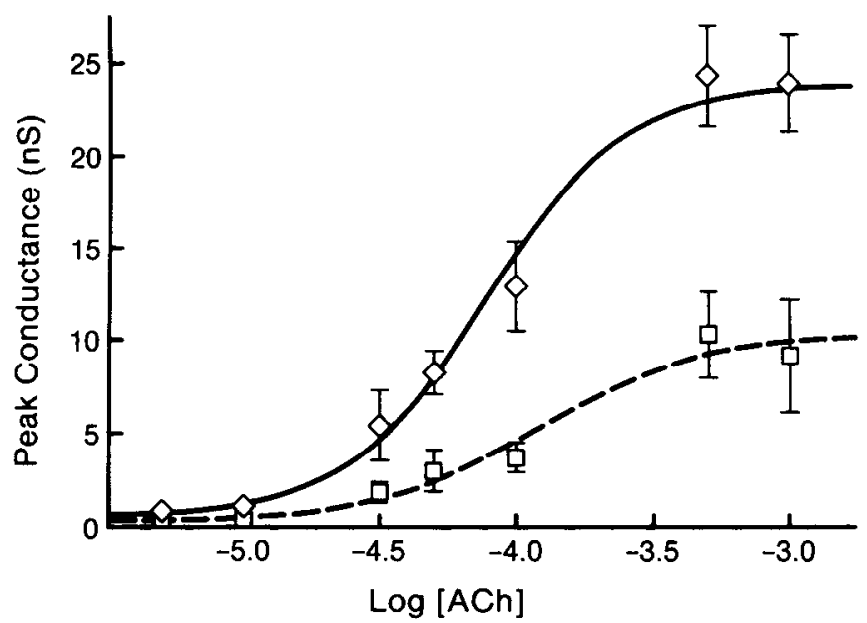

Figure 3. Whole-cell ACh dose-response relationship. Neurons were grown in either $\mathrm{K}^{+} /$eye (squares) or eye (diamonds) media and exposed to $\mathrm{ACh}$ in recording solution at the indicated concentrations. Each determination represents the mean extrapolated peak ACh conductance ( \pm SEM) obtained from 4-18 neurons in 2-4 separate culture platings. The curves were fitted to the data using a least-squares nonlinear regression routine. The routine predicted $K_{\mathrm{d}}$ values of 100 and $80 \mu \mathrm{M}$ and Hill coefficients of 1.5 and 1.7 for ACh responses of neurons grown in $\mathrm{K}^{+} /$eye and eye media, respectively.

\begin{tabular}{lclll}
\hline Table 1. & Whole-cell AChR parameters & & \\
$\begin{array}{l}\text { Growth } \\
\text { medium }\end{array}$ & $\begin{array}{l}G_{\mathrm{A}} \\
(\mathrm{nS})\end{array}$ & $\begin{array}{l}G_{\mathrm{C}} \\
(\mathrm{nS})\end{array}$ & $\begin{array}{l}\gamma_{\mathrm{a}} \\
(\mathrm{pS})\end{array}$ & $\begin{array}{l}\tau_{\mathrm{b}} \\
(\mathrm{msec})\end{array}$ \\
\hline $\mathrm{K} / \mathrm{eye}$ & $3.7 \pm 0.7$ & $0.9 \pm 0.3$ & $34 \pm 7$ & $4.0 \pm 0.4$ \\
& $(14)$ & $(6)$ & $(8)$ & $(8)$ \\
Eye & $12.9 \pm 2.5$ & $2.8 \pm 0.3$ & $31 \pm 2$ & $3.5 \pm 0.3$ \\
& $(12)$ & $(6)$ & $(23)$ & $(23)$
\end{tabular}

Whole-cell analysis of AChR function in ciliary ganglion neurons grown in $\mathrm{K}^{+}$ supplemented ( $\mathrm{K}^{+} /$eye) or normal (eye) medium. All values are presented as the mean \pm SEM, with the number of neurons tested in parentheses. $G_{\mathrm{A}}$ and $G_{\mathrm{C}}$ are the maximal peak whole-cell conductance increases induced by application of ACh or carbamylcholine, respectively (both applied at $100 \mu \mathrm{M}$ ). $G_{\mathrm{A}}$ and $G_{\mathrm{C}}$ were calculated from the relation $G=I /\left(V_{\mathrm{h}}-V_{\mathrm{r}}\right)$, where $I$ is the extrapolated maximal peak current and $V_{\mathrm{h}}$ is the holding potential. Based on single-channel measurements (Table 2), a reversal potential $\left(V_{r}\right)$ of $-9 \mathrm{mV}$ was assumed for both agonists. The apparent single-channel conductance $\left(\gamma_{a}\right)$ and open (burst) duration $\left(\tau_{b}\right)$ were determined by analyzing the whole-cell current fluctuations induced by $10 \mu \mathrm{M}$ ACh (Fig. 4).

holding potentials and measuring the slope of the peak currentvoltage relationship (Fig. $1 B$ ) or by assuming a reversal potential and calculating the conductance from a single $A C h$ application (Table 1). Whole-cell conductance measurements obtained from the 2 approaches were indistinguishable. For the first approach, neurons grown in $\mathrm{K}$ / $/$ eye medium had slope conductances of 2-4 nS $(n=3)$, one-third or less than the value obtained for neurons grown in normal eye medium $(n=3$ ) (e.g., Fig. $1 B)$. The whole-cell current-voltage relationship was linear for holding potentials of -100 to $-20 \mathrm{mV}$, but clear reversal of the whole-cell ACh-induced current was not observed. Nevertheless, the values obtained by extrapolation for the apparent $\mathrm{ACh}$ reversal potential were nearly identical for the growth conditions (Fig. $1 B$, dashed lines). The observation that whole-cell $\mathrm{ACh}$ currents did not reverse may reflect strong voltage dependencies of the opening probability and open lifetime of individual AChR channels. One consequence of this is that the true reversal potential of whole-cell ACh currents could not be calculated accurately by linear extrapolation. Thus, for the second approach, in which ACh was applied to the cell once at holding potentials from -60 to $-75 \mathrm{mV}$, we used a reversal potential obtained from single-channel measurements $\left(V_{\mathrm{r}}=-9 \mathrm{mV}\right.$ ) (see Fig. 5 and Table 2). Again, the mean whole-cell conductance induced by $100 \mu \mathrm{M}$ ACh for neurons grown in $\mathrm{K}^{+}$/eye medium was about one-third that obtained for neurons grown in eye medium (Table 1).

The lower ACh sensitivity of neurons grown in elevated $\mathrm{K}^{+}$ is not an artifact of acute $\mathrm{K}^{+}$exposure. Using intracellular voltage recording techniques, it was found that neurons grown in eye medium and then switched to $\mathrm{K}^{+} /$eye medium for $2 \mathrm{hr}$ showed conductance responses to $100 \mu \mathrm{M} \mathrm{ACh}$ that were not significantly different from controls (Fig. 2). Extending the incubation time in $\mathrm{K}^{+}$/eye medium up to $72 \mathrm{hr}$, however, revealed a gradual decline in ACh sensitivity with a half-decay time of $11 \mathrm{hr}$ to reach the equilibrium value.

Dunn and Marshall (1985) have proposed that the denervation-induced hypersensitivity of bullfrog sympathetic neurons to $\mathrm{ACh}$ results from a decrease in cholinesterase activity. An increase in cholinesterase activity cannot explain the reduced ACh-sensitivity of ciliary ganglion neurons grown in $\mathrm{K}^{+}$/eye medium, because carbamylcholine, a synthetic agonist that is only slowly hydrolyzed, reveals the same differences detected with ACh (Table 1). 

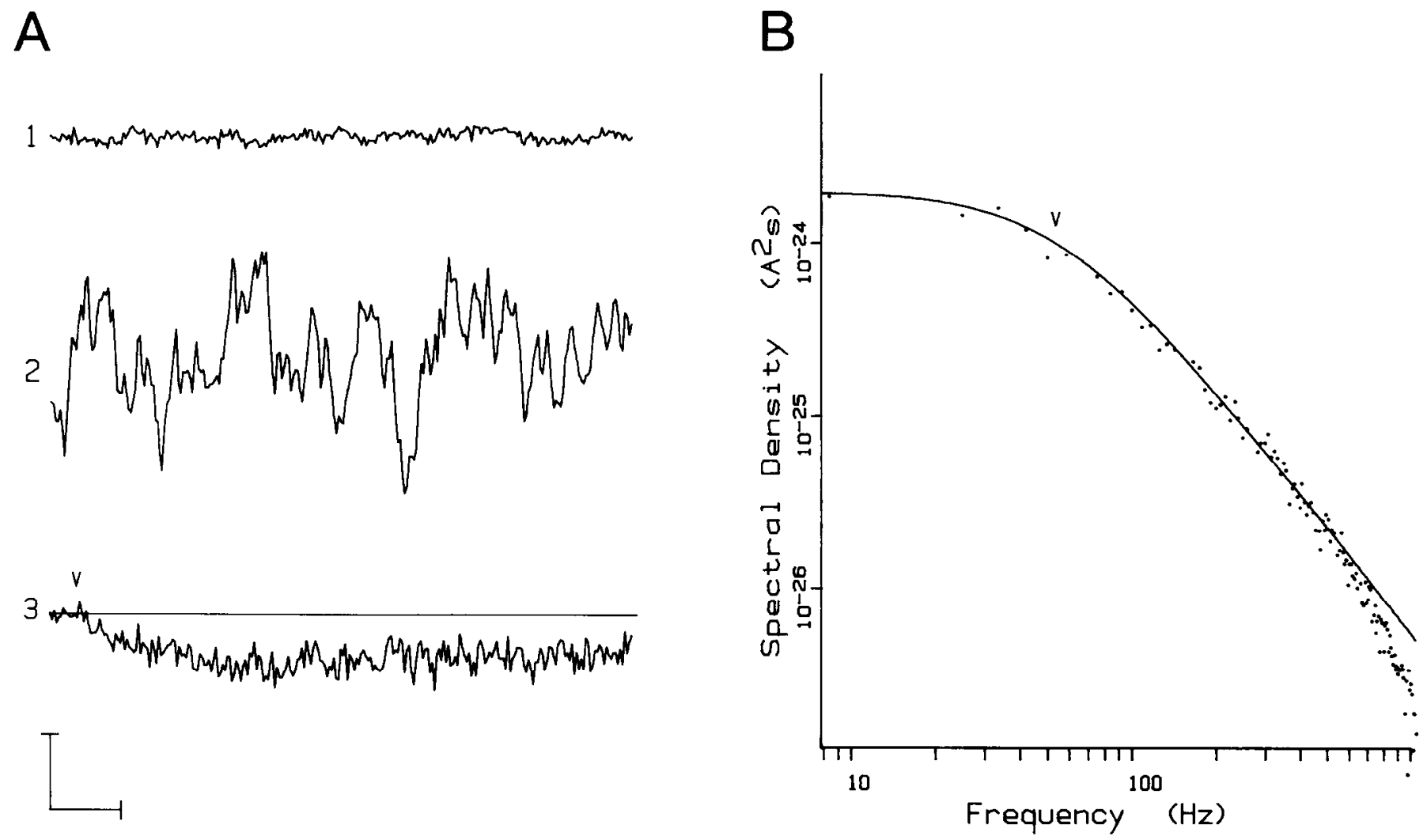

Figure 4. Whole-cell ACh-induced current fluctuations. $A$, Samples of whole-cell current recorded at $-65 \mathrm{mV}$ from a neuron grown in eye medium for $6 \mathrm{~d}$. The top 2 traces depict the whole-cell current before $(I)$ and during (2) exposure to $10 \mu \mathrm{M} \mathrm{ACh}$, recorded at high gain (vertical calibration, $20 \mathrm{pA}$ ) with the currents filtered $(-3 \mathrm{~dB}, 1000 \mathrm{~Hz}$ ), and digitally sampled every $500 \mu \mathrm{sec}$ (horizontal calibration, $60 \mathrm{msec}$ ). The lower trace (3) shows an unfiltered recording of the whole-cell current at low gain (vertical calibration, $100 \mathrm{pA}$ ) and reduced time resolution (horizontal calibration, $1 \mathrm{sec})$. The mean current $(I)$ induced by application of $10 \mu \mathrm{M} \mathrm{ACh}$, begun at the carat and continuing for the duration of the recording, was - 61 pA. $B$, Spectral density plot of current fluctuations obtained from the neuron depicted in $A$. A Lorentzian theory (Eq. 1; solid line) was fitted by eye. Corner frequency, $f_{\mathrm{c}}-53 \mathrm{~Hz}$ (carat), zero frequency amplitude, $S(0)=1.96 \times 10^{-24} A^{2} s$. A single AChR channel conductance of $45 \mathrm{pS}$ was calculated from these values and the mean current using Equation 2, assuming an ACh current reversal potential of $-9 \mathrm{mV}$. The apparent channel burst duration was estimated as $3.0 \mathrm{msec}$, using the relation $\tau_{\mathrm{b}}=1 / 2 \pi f_{\mathrm{c}}$.

The differences between the $\mathrm{ACh}$ responses of neurons from the 2 growth conditions do not reflect differences in the agonist affinity of receptors. The apparent affinity of neuronal AChRs was estimated from the responses of cells exposed to ACh concentrations between $5 \mu \mathrm{m}$ and $1 \mathrm{~mm}$. Peak ACh-induced wholecell conductances obtained from neurons grown in $\mathrm{K}^{+} /$eye medium were about one-third the size of those from neurons grown in eye medium at all concentrations examined (Fig. 3). Responses in both cases were just detectable at $5 \mu \mathrm{M}$ and saturated at $500 \mu \mathrm{M}$ (Fig. 3). The dose-response relationships were fitted using a nonlinear, least-squares regression; the apparent $K_{\mathrm{d}} \mathrm{s}$ and Hill coefficients obtained for both growth conditions were similar (100 $\mu \mathrm{M}$ and $1.5, \mathrm{~K}^{+}$/eye medium; $80 \mu \mathrm{M}$ and 1.7 , eye medium).

AChR current fluctuations. The apparent burst duration and conductance of the entire population of AChRs on the neurons was assessed by analyzing whole-cell current fluctuations evoked by $10 \mu \mathrm{M} \mathrm{ACh}$. This concentration was high enough to give wellresolved currents from cells grown either in normal or elevated $\mathrm{K}^{+}$, and low enough that the mean current levels remained fairly constant. Figure 4 typifies the responses observed in neurons grown in eye medium. Application of $10 \mu \mathrm{M}$ ACh to a neuron held at $-65 \mathrm{mV}$ induced both a sustained inward current, as seen at low gain (Fig. 4A,3), and a dramatic increase in the current noise seen at high gain (compare Fig. $4 A, 2$ to 1). The power spectra of the ACh-induced current fluctuations for this neuron were well fitted by a single Lorentzian function (Eq. 1; Fig. 4B), which predicted an apparent burst duration of $3 \mathrm{msec}$ and an apparent single-channel conductance of $45 \mathrm{pS}$. In separate experiments in which $25 \mu \mathrm{M} d$-tubocurarine was pressureapplied to neurons, spontaneous synaptic potentials were abolished, indicating that pressure-applied ligands gain access to soma membrane AChRs, including those associated with synapses formed between the neurons (Margiotta and Berg, 1982). Taken together, the findings are consistent with the neurons' having a single class of functional AChRs. Similar noise spectra were obtained for neurons grown in $\mathrm{K}^{+}$/eye medium, except that the spectral densities were smaller, as expected from their smaller mean currents. There were no differences between the mean values for apparent burst duration or conductance for neurons from the 2 growth conditions (Table 1).

\section{Single-channel currents}

Permeation properties. In the absence of applied ACh, recordings from excised outside-out patches of neuron somata membrane generally showed few if any single-channel currents. The events that were observed probably did not arise from openings of unbound AChR channels (Jackson, 1986) because the events had a smaller conductance ( $20-30 \mathrm{pS})$ and a more positive re- 

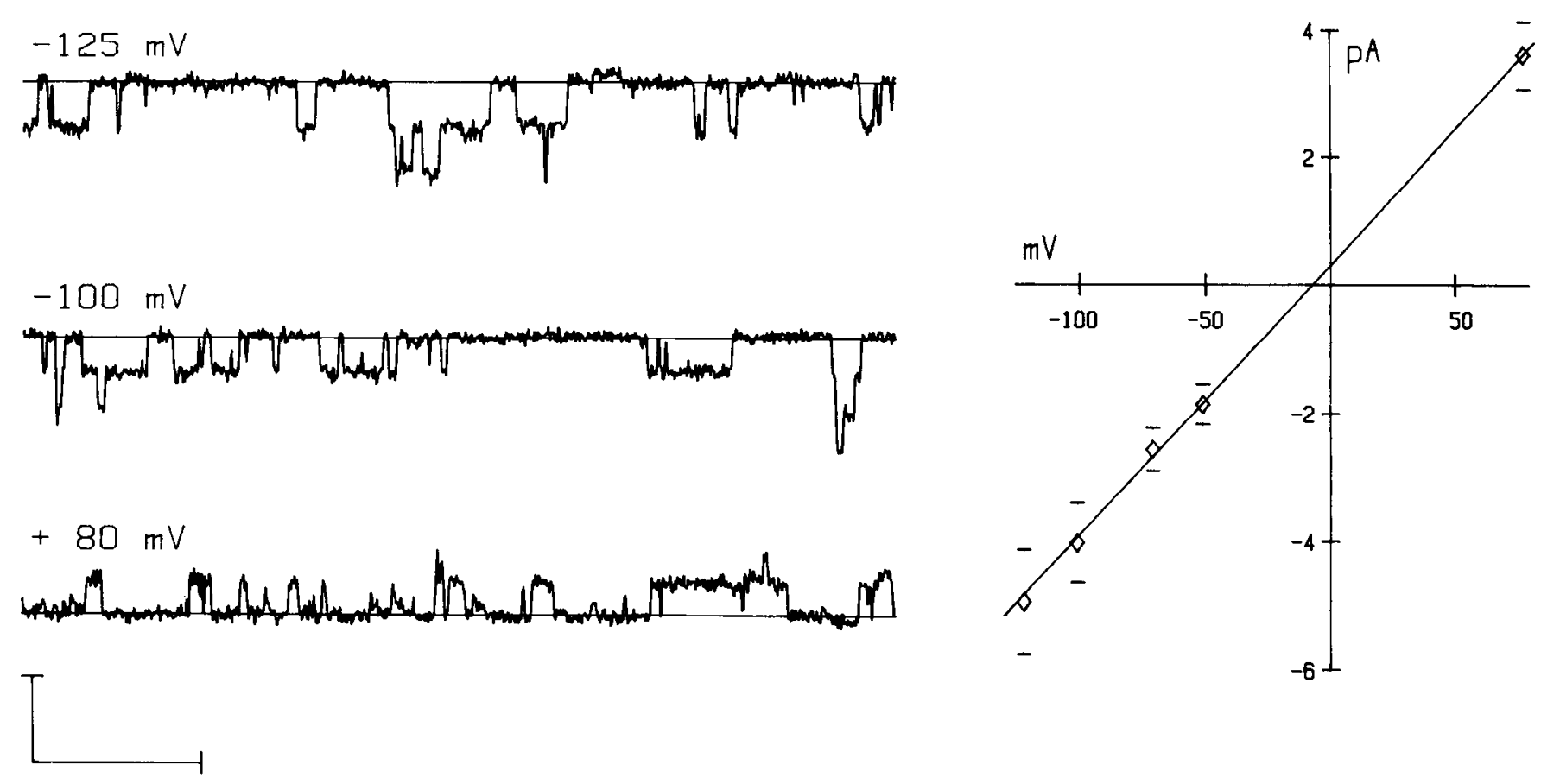

Figure 5. AChR single-channel currents. $A$, Single-channel current records were obtained from a high-resistance (5 G $\Omega$ ) outside-out patch of soma membrane excised from a neuron grown in eye medium for $7 \mathrm{~d}$. ACh $(5 \mu \mathrm{M})$ was applied to the patch at 5 different holding potentials, records from 3 of which are shown. Calibrations; $10 \mathrm{pA}$ vertical, $20 \mathrm{msec}$ horizontal. $B$, Current-voltage relation for the single-channel currents recorded from this patch. Each point represents 100-1400 events. The line was drawn by linear regression giving a slope conductance of $42 \mathrm{pS}$ and a reversal potential of $-8 \mathrm{mV}$.

versal potential $(0-10 \mathrm{mV})$ than did AChR-channel currents. Patches that displayed such "spontaneous" events were not included in the present study. Of all outside-out patches examined from neurons grown in eye $(n=36)$ and $\mathrm{K}^{+} /$eye $(n=20)$ media, 90 and $70 \%$, respectively, showed some single-channel current events when exposed to ACh. The frequency of events in most patches was variable, although generally quite low, suggesting that the overall density of functional AChRs on the neurons in culture is small. This finding precluded the use of ACh concen- trations below $1 \mu \mathrm{M}$. ACh concentrations higher than $5 \mu \mathrm{M}$ appeared to cause desensitization.' Because of these constraints, ACh concentrations of 2-5 $\mu \mathrm{M}$ were used in all single-channel experiments. Since these concentrations kept the sustained rate of channel activation low, the appearance of multiple or overlapping events was aiso low. Nevertheless, the typical AChsensitive patch contained more than one functional AChR channel, as indicated by occasional multiple events.

Portions of a record from an outside-out patch of soma mem-

\section{Table 2. Single AChR channel parameters}

\begin{tabular}{llllll}
$\begin{array}{l}\text { Growth } \\
\text { medium }\end{array}$ & $\begin{array}{l}V_{\mathrm{r}} \\
(\mathrm{mV})\end{array}$ & $\begin{array}{l}\gamma \\
(\mathrm{pS})\end{array}$ & $\begin{array}{l}\tau_{\mathrm{a}} \\
(\mathrm{msec})\end{array}$ & $\begin{array}{l}\beta \\
\left(\mathrm{sec}^{-1}\right)\end{array}$ & $\begin{array}{l}k_{-} \\
\left(\mathrm{sec}^{-1}\right)\end{array}$ \\
\hline K+/eye & $-10.8 \pm 3.5$ & $40.8 \pm 2.1$ & $0.9 \pm 0.2$ & $500 \pm 29$ & $767 \pm 67$ \\
& $(7)$ & $(7)$ & $(3)$ & $(3)$ & $(3)$ \\
Eye & $-8.4 \pm 2.1$ & $40.2 \pm 1.8$ & $1.0 \pm 0.1$ & $525 \pm 43$ & $817 \pm 93$ \\
& $(10)$ & $(10)$ & $(3)$ & $(3)$ & $(3)$ \\
Pooled & $-9.4 \pm 1.9$ & $40.5 \pm 1.3$ & $1.0 \pm 0.1$ & $513 \pm 24$ & $792 \pm 52$ \\
& $(17)$ & $(17)$ & $(6)$ & $(6)$ & $(6)$
\end{tabular}

Single-channel data were obtained from outside-out patches excised from ciliary ganglion neurons grown in $\mathrm{K}^{+} / \mathrm{eye}$ or eye media; methods and theoretical considerations are described in the text and in legends for Figures 5 and 6 . The single-channel parameters are expressed as the mean $\pm S E M$, with the number of patches examined in parentheses. $V_{r}$, Reversal potential of single AChR channel current; $\gamma$, single AChR channel conductance; $\tau_{\mathrm{a}}$, apparent mean channel open time; $\beta$, opening rate constant; $k_{-}, \mathrm{ACh}$ unbinding rate constant. Since no significant difference was revealed for the parameters obtained from neurons grown in the different media ( $p>0.2$ in all cases), the pooled results are also presented. The kinetic parameters $\left(\tau_{\mathrm{a}}, \beta\right.$, and $\left.k_{-}\right)$are presented only for those patches that were held at a potential in the range -75 to $-100 \mathrm{mV}$ and that displayed greater than 600 events (mean of 700 events). Values of $\tau_{\mathrm{a}}$ were similar when evaluated for other patches displaying fewer events and held at the same voltages (range, $0.8-1.3 \mathrm{msec} ; 4$ additional patches for each growth condition). 

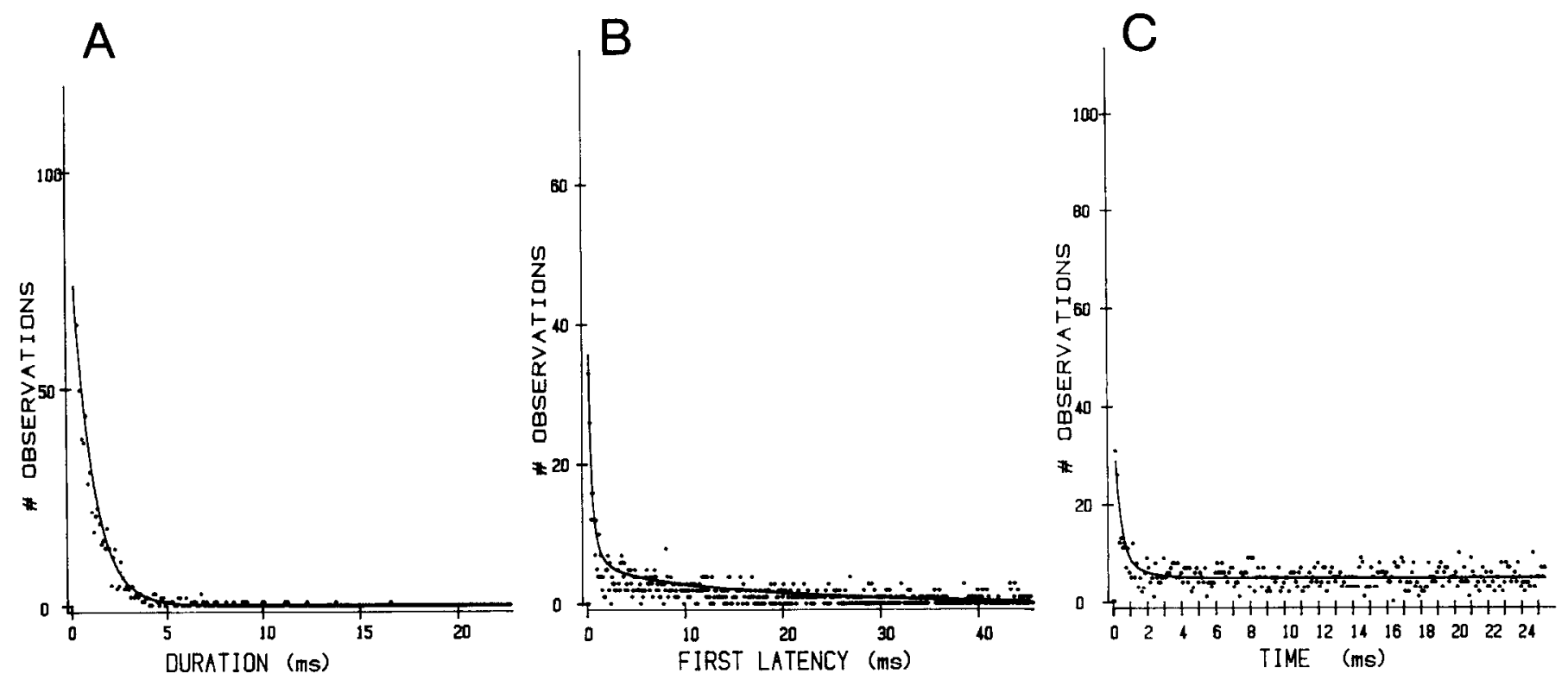

Figure 6. AChR kinetics. The data are taken from single AChR channel currents collected at $-100 \mathrm{mV}$ from the patch depicted in Figure 5 . Measured open and closed durations $(A, B)$ and the closed time between a closing transition and the next opening $(C)$ were assembled into histograms (filled circles, $100 \mu \mathrm{sec}$ bin widths) for analysis. $A$, Distribution of single AChR channel open durations. The distribution was fitted by an exponential function (solid line) having a time constant equal to the apparent mean channel open time (here $0.9 \mathrm{msec}^{\circ} \alpha=1 / \tau_{\mathrm{a}}=1120 \mathrm{sec}^{-1}$ ), determined by a maximum likelihood method. $B$, Distribution of closed intervals between openings. The distribution shows that shorter closed durations predominate. Data were fitted to the histogram with an equation based on a kinetic model having 3 closed states (Scheme 3) (see text and Dionne and Leibowitz, 1982; Leibowitz and Dionne, 1984, for details), which includes the parameters $\beta$ and $k_{-}$. These parameters are adjusted to provide the best fit of the theory to the data (here $\beta=600 \mathrm{sec}^{-1}$ and $k_{-}=1000 \mathrm{sec}^{-1}$ ). Note that the theory (solid line) provides an approximate fit to the data. $C$, Opening rate distribution. The histogram shows the times at which single-channel opening transitions occurred during the $25.6 \mathrm{msec}$ period following any channel closing transition. The data show that, except for the first few milliseconds following a channel closure, the probability of channel opening was time-independent. During the first few milliseconds, however, the opening probability was substantially higher. Data were fitted to an expression predicting the probability of channel opening after a closing transition (solid line), as derived by Dionne and Leibowitz (1982).

brane excised from a neuron grown in eye medium and exposed to $5 \mu \mathrm{M} A C h$ are shown in Figure $5 \mathrm{~A}$. The rectangular current deflections represent the opening of single AChR channels; they were absent when the patch was perfused with recording solution not containing $\mathrm{ACh}$. There were at least 3 active channels in this patch, as shown by the overlapping events. The currents flowed inward (down) at $-100 \mathrm{mV}$, increasing in amplitude at $-125 \mathrm{mV}$, and flowed outward (up) at $+80 \mathrm{mV}$. In analyzing the data, the amplitude, duration, and time between each transition in the record were measured. Histograms of single-channel current amplitudes were constructed for the voltages examined, and the mean single-channel current was plotted against the pipette holding potential (Fig. $5 B$ ). The ACh-induced currents in this patch reversed sign at $-8 \mathrm{mV}$, and the slope of the current-voltage relation gave a single-channel conductance of $42 \mathrm{pS}$. These values are nearly identical to the means obtained from 17 patches excised from neurons grown in either normal or elevated $\mathrm{K}^{+}$(Table 2 ).

The equilibrium dissociation constant $\left(K_{\mathrm{d}}\right)$ for ACh binding was estimated using the results of the whole-cell dose-response measurements. Hill coefficients close to 2, such as those obtained here, are generally taken to imply that occupation of 2 agonist sites per receptor is required for activation. If $q$ is the probability that a binding site on a receptor will be occupied, then $q^{2}$ is the probability that both sites will be occupied, assuming that the sites are identical, have equal affinity, and behave independently. Half-maximal responses were obtained from neurons grown in eye and $\mathrm{K}^{+} /$eye medium using 80 and $100 \mu \mathrm{M}$
ACh (Fig. 3), suggesting that half of the receptors had both sites occupied at these concentrations $\left(q^{2}=0.5\right)$. Since $q$ is the fraction of bound sites, and $1-q$ the fraction of free sites, the $K_{\mathrm{d}}$ will be given by $[\mathrm{ACh}](1-q) / q$. Thus, values of 33 and $40 \mu \mathrm{M}$ were obtained for the $K_{\mathrm{d}} \mathrm{s}$. Since the difference in $K_{\mathrm{d}}$ is small, a nominal value of $36 \mu \mathrm{M}$ was used to calculate kinetic parameters from the single-channel experiments.

Kinetic properties. The kinetic behavior of $\mathrm{AChR}$ channels on the neurons was evaluated from the stochastic properties of the time intervals between opening and closing transitions in the single-channel current records. This was done by constructing histograms of channel open and closed durations, and of channel opening frequencies. The histograms were fitted well by a simple scheme that has also been used to describe the kinetics of muscle endplate AChR channels (del Castillo and Katz, 1957; Dionne and Leibowitz, 1982) and that is a first approximation of more complicated kinetics observed for perijunctional AChR channels (Colquhoun and Sakmann, 1985) and nonjunctional AChR channels (Sine and Steinbach, 1986).

The distribution of observed open-channel durations was well described by a single-exponential curve (Fig. 6A), while the distribution of observed closed durations had several components (Fig. 6B). This finding supports a model such as Scheme 3 (below), with one open state and several closed states. The simplicity of the open duration distribution also adds support to the idea of a single, homogenous population of functional channels on the neurons, which was suggested by the spectral analysis of whole-cell current fluctuations (Fig. 4). The apparent 
mean channel open time $\left(\tau_{\mathrm{a}}\right)$ was estimated to be the time constant of a single-exponential curve fitted to the open duration histogram (Fig. 6A), using a maximum likelihood method (Colquhoun and Sigworth, 1983). The apparent mean open time, from patches held at potentials ranging from -75 to $-100 \mathrm{mV}$, was about $1 \mathrm{msec}$ and was not affected by the different growth conditions (Table 2). The measured open and closed durations are termed "apparent" here to emphasize that unresolved brief gaps necessarily corrupt the measurements. Although the analytical problems that result from the unresolved gaps are complicated and may influence estimates of the kinetic rates (Roux and Sauve, 1985; Blatz and Magleby, 1986), they would not be expected to produce false differences in the kinetic properties of neurons grown under the different conditions.

The first latency histogram (Fig. 6B) shows the distribution of closed intervals between openings. It illustrates the timedependent probability that an opening transition will occur at a time $t$ after a closing transition ( $t=0$, all channcls closed), and with no openings in the interval $(0, t)$. Unlike the open duration histogram, this distribution could not be fitted by a single exponential, but instead required use of a function closely approximated by the sum of 3 exponentials (see below).

The opening rate histogram in Figure $6 C$ represents the frequency of AChR-channel openings following a closing transition. For times longer than aboul $2 \mathrm{msec}$ after a closing, this frequency was constant, indicating that the opening probability was independent of prior channel activity. However, immediately after a channel closed, the opening probability was enhanced, and it decayed during a few milliseconds to the value characteristic of later times. Thus, individual openings of $\mathrm{AChR}$ channels do not behave independently; instead, it is more likely that an opening transition will occur immediately after a closing transition. This is not necessarily evidence of activation-coupling between channels, but is to be expected if the channel that just closed can reopen readily.

A relatively simple receptor-activation model featuring 1 open and 3 closed states (Scheme 3) was sufficient, as a first approximation, for describing the histograms in Figure 6. Assuming that an $\mathrm{AChR}$ channel is closed when both $\mathrm{ACh}$ binding sites are free, and that the binding of $2 \mathrm{ACh}$ molecules greatly increases the opening probability [supported by IIill coefficients close to 2 for muscle AChRs (Dionne et al., 1978) and for AChRs on ciliary ganglion neurons (Fig. 3)] the kinetics of sequential binding and activation can be represented as

$$
2 A+R \underset{k_{-}}{\stackrel{2 k_{+}}{\rightleftharpoons}} A+A R \underset{2 k_{-}}{\stackrel{k_{+}}{\rightleftharpoons}} A_{2} R \underset{\alpha}{\stackrel{\beta}{\rightleftharpoons}} A_{2} R^{*} .
$$

In this scheme, $A$ denotes agonist, $R$ the receptor-channel complex, and $A_{2} R^{*}$ the only open-channel state. The 3 other states represent closed configurations of the receptor-channel complex, with 0,1 , or 2 agonist molecules bound. The binding parameters $k_{+}$and $k_{-}$are microscopic rate constants of agonist association and dissociation, with $K_{\mathrm{d}}=k_{-} / k_{+}$. Transition rate constants for channel opening and closing are given by $\beta$ and $\alpha$, respectively.

We used single-channel ensemble analysis (Dionne and Leibowitz, 1982; Leibowitz and Dionne, 1984) to estimate the rate constants $\alpha, \beta$, and $k_{-}$in Scheme 3 by fitting the predicted distributions to the actual open duration, first latency, and opening rate histograms, such as those in Figure 6. Unlike other methods used to assess channel kinetics (e.g., Colquhoun and
Hawkes, 1982), this method may be applied to data from patches containing an unknown number of active channels, since the number of channels is one of the parameters evaluated. A detailed treatment of this analytical method and the quantitative expressions involved is given in the references cited.

The kinetic dissociation and transition rate constants were evaluated and found to be independent of the growth conditions. The closing rate constant, $\alpha$, was estimated as the reciprocal of the apparent mean channel open time. By fitting the opening rate and first latency histograms, the rate constants $\beta$ and $k_{-}$ were independently estimated. As shown in Figure 6 , the histograms were fitted reasonably well by the theory, which predicted values of $1120 \mathrm{sec}^{-1}$ for $\alpha, 600 \mathrm{sec}^{-1}$ for $\beta$, and 1000 $\sec ^{-1}$ for $k_{\text {- }}$ for the single-channel data depicted in Figure 5. In 6 patches held at potentials from -75 to $-100 \mathrm{mV}$, sufficient numbers of events were collected to estimate $\tau_{\mathbf{a}}, \beta$, and $k_{-}$(Table 2 ). The mean values obtained were not different for neurons grown in eye and $\mathrm{K}^{+} /$cye media.

\section{Discussion}

\section{AChR function}

No differences were detected between the functional properties of individual nicotinic AChRs on chick ciliary ganglion neurons grown in normal and elevated concentrations of $\mathrm{K}^{+}$. The properties examined were based on both whole-cell and single-channel recordings and included apparent rates of receptor desensitization, affinity and Hill coefficient for agonist binding, single AChR channel conductance, reversal potential, open duration, and opening rate constant.

The functional properties of AChRs on the neurons display a number of similarities to AChRs on skeletal muscle fibers. Our estimates for the AChR-channel conductance and open time, derived from whole-cell current noise spectra (35 pS and $3.5 \mathrm{msec}$ ) and single-channel measurements ( $40 \mathrm{pS}$ and $1.0 \mathrm{msec}$ ), are comparable to values obtained in frog and rat muscle using the same techniques of noise analysis (Anderson and Stevens, 1973; Neher and Sakmann, 1976; Sakmann, 1978) and singlechannel recording (Hamill and Sakmann, 1981; Brehm et al., 1984). Similar values have also been reported for AChR channels on chick muscle by means of noise analysis ( $40 \mathrm{pS}$ and 5 msec; Fischbach and Lass, 1978) and single-channel recording (48 pS and 3.2 msec; Jackson and Lecar, 1979). The reversal potential of $-9 \mathrm{mV}$ for the AChR channel on the neurons is similar to that reported for muscle AChRs, and suggests a general permeability to cations. Desensitization of AChRs on the neurons was characterized by fast and slow components similar to those previously described for muscle AChRs (Sakmann et al., 1980; Feltz and Trautmann, 1982). The $K_{\mathrm{d}}$ of about $36 \mu \mathrm{M}$ for $\mathrm{ACh}$ binding by the neuronal receptor is similar to the values of 28 and $15 \mu \mathrm{M}$ reported for electric tissue and muscle AChRs, respectively (Sheridan and Lester, 1977; Dreyer et al., 1978). The Hill coefficients of 1.5-1.7 obtained here for the neuronal $\mathrm{AChR}$ are similar to the value of 2 previously reported for AChRs on ciliary ganglion neurons in vivo (Brenner and Martin, 1976), and to the values of 1.5-1.8 reported for muscle AChRs (Hartzell et al., 1975; Dionne et al., 1978), suggesting that this neuronal receptor also has 2 agonist binding sites that must be occupied for activation.

The kinetic behavior of AChR channels on the neurons was compared with predictions from a simple model featuring 2 ACh binding sites per receptor, with each receptor having 3 closed states and 1 open state. Use of this model was supported 
by Hill coefficients close to 2 , by single-component open duration distributions and multiple-component closed duration distributions. Although the open duration, first latency, and opening rate histograms fit the predictions of the model reasonably well, events briefer than $200 \mu \mathrm{sec}$ were excluded during analysis. Any excess or deficit of very brief events would require a more complicated model and reinterpretation of the kinetic rate constants. For this reason, the model is presented only as a first approximation; its general usefulness needs to be examined further. Nevertheless, the predicted mean rate constants for ncuronal AChR-channel opening $\left(\beta=513 \mathrm{sec}^{-1}\right)$ and agonist unbinding $\left(k_{.}=792 \mathrm{sec}^{-1}\right)$ are close to the values of $\beta(150$ $\left.1200 \mathrm{sec}^{-1}\right)$ and $k$. $\left(900 \mathrm{sec}^{-1}\right)$ reported for AChRs on clonal mammalian BC3H-1 cells (Sine and Steinbach, 1986). At the snake neuromuscular junction, a similar value for $\beta$ was obtained (750-825 $\left.\mathrm{sec}^{-1}\right)$, although $k_{-}\left(1700-3000 \mathrm{sec}^{-1}\right)$ was somewhat higher (Dionne and Leibowitz, 1982; Leibowitz and Dionne, 1984). The predicted mean closing rate constant for neuronal AChRs $\left(\alpha=1000 \mathrm{sec}^{-1}\right)$ is close to that reported for AChRs at snake and frog neuromuscular junctions (ca. $700 \mathrm{sec}^{-1}$ ), which also show brief open-channel durations (Dionne and Leibowitz, 1982; Leibowitz and Dionne, 1984; Colquhoun and Sakmann, 1985), but is much higher than that observed for receptors on $\mathrm{BC} 3 \mathrm{H}-1$ cells $\left(20-60 \mathrm{sec}^{-1}\right)$, which display unusually long-duration openings (Sine and Steinbach, 1986).

Previous patch-clamp recording studies on ciliary ganglion neurons grown in elevated $\mathrm{K}^{+}$concentrations also presented evidence for a single class of functional AChRs on the neurons, and produced values for the AChR single-channel conductance and mean channel open time (Ogden et al., 1984) that are similar to those reported here. A value of $+10 \mathrm{mV}$ was reported for the reversal potential, however, which differs from the value obtained here, and may reflect the fact that the earlier measurements were made in the "cell-attached" recording mode, where the transmembrane potential of the patch was unknown. That earlier study also reported a lower affinity for agonist activation of the neuronal AChR than was observed here. Possibly receptor desensitization played a larger role in the earlier determination, since agonist was bath-applied to the cultures rather than applied by rapid microperfusion to individual neurons as in the present study.

A longer apparent open time was obtained for the neuronal AChR channel from noise measurements than from singlechannel recordings. This was expected because noise spectra have a characteristic time constant, dominated by a component nearly equal to the apparent burst duration, i.e., the time spent in the liganded states $A R, A_{2} R$, and $A_{2} R^{*}$ (Scheme 3; Colquhoun and Hawkes, 1981), whereas single-channel measurements evaluate the apparent open time of $A_{2} R^{*}$ only. The same consideration can account for the different $\mathrm{AChR}$ open times estimated in muscle using the 2 techniques (Anderson and Stevens, 1973; Dionne and Parsons, 1981; Dionne and Leibowitz, 1982; Brehm et al., 1984). The disparity between the time constant of the whole-cell noise spectrum and the single AChR channel open time reported here, however, is greater than expected from the kinetic model fitted to the data. The rate constants estimated from the single-channel data predict a dominant noise time constant of about $2.0 \mathrm{msec}$, not $3.5-4.0 \mathrm{msec}$. The reason for the disparity between predicted and measured values is unclear. It could reflect a difference in the behavior of $A C h R$ channels in the excised, outside-out patch and the whole cell, or a deficiency in the kinetic model.

\section{$A C h R$ regulation}

The whole-cell voltage-clamp studies reported here confirm previous intracellular recordings showing that growth of neurons in high concentrations of $\mathrm{K}^{+}$reduces the ACh response (Smith et al., 1983). Ogden et al. (1984) also observed low ACh sensitivities for ciliary ganglion neurons grown in elevated $\mathrm{K}^{+}$concentrations; neurons grown in normal medium apparently were not examined. The altered $\mathrm{ACh}$ response cannot be accounted for by changes in apparent rates of AChR desensitization or in the single-channel properties, as described above. It cannot be accounted for by an acute effect of the $\mathrm{K}^{+}$, since the decline in ACh sensitivity occurs with a half-time of about $11 \mathrm{hr}$. Nor can it be accounted for by changes in cholinesterase activity, since similar results are obtained with the agonists $\mathrm{ACh}$ and carbamylcholine. The reduced response is also unlikely to reflect a migration of receptors away from the soma to neurites outside of the range of voltage control provided by the voltage clamp: autoradiographic experiments with ${ }^{125} \mathrm{I}-\mathrm{mAb} 35$ reveal no differences in the distribution of AChRs on neurons grown in normal and elevated $\mathrm{K}^{+}$(Smith et al, 1986). The remaining explanation is that the lowered sensitivity represents a reduction in the number of functional AChRs on the neurons.

The mechanisms by which growth in $\mathrm{K}^{+}$/eye medium could reduce the number of functional AChRs are unknown. One possibility is that, by depolarizing the neurons, elevated $\mathrm{K}^{+}$ triggers release of $\mathrm{ACh}$ from presynaptic terminals in the cultures (Margiotta and Berg, 1982), which then reduces the number of functional AChRs by agonist-induced interactions. Growth in carbamylcholine reduces the ACh sensitivity of both skeletal myotubes (Noble et al., 1978) and ciliary ganglion neurons in culture (Smith et al., 1986).

The number of activatable AChRs per neuron soma can be estimated from whole-cell $\mathrm{ACh}$ responses and single-channel parameters, assuming that the whole-cell recordings resolve the fastest components of neuronal $\mathrm{AChR}$ desensitization. This assumption is supported by experiments in muscle that reveal a fast component of AChR desensitization with a time constant of 0.3-2.0 sec (Sakmann et al., 1980; Feltz and Trautman, 1982; Adams and Bevan, 1985), similar to that reported here, and certainly within resolution using rapid microperfusion of agonist. In clonal $\mathrm{BC} 3 \mathrm{H}-1$ cells, however, AChR desensitization has been reported to be more rapid and is apparently complete within $100 \mathrm{msec}$ (Brett et al., 1986). The presence of a comparably rapid component of neuronal $\mathrm{AChR}$ desensitization would have been largely undetected in the present assay, causing the extrapolated maximal whole-cell current to be somewhat underestimated. The limiting values for maximal $\mathrm{ACh}$-induced whole-cell conductances $\left(G_{\mathrm{A}}\right)$, obtained using $500 \mu \mathrm{M} \mathrm{ACh}$, and corrected for fast desensitization ( $0.5-0.8 \mathrm{sec}$ time constant), were about $27 \mathrm{nS}$ and $10 \mathrm{nS}$ for neurons grown in eye and $\mathrm{K}^{+} /$ eye media, respectively (Fig. 3). Assuming that all receptors are in the $A_{2} R$ state when exposed to $500 \mu \mathrm{M} \mathrm{ACh}$, the number of functional $A C h R$ channels on the neuron soma will be given by $N_{\mathrm{f}}=G_{\mathrm{A}} / p \gamma$, where $\gamma$ is the single-channel conductance $(40 \mathrm{pS})$, and $p$ is the single-channel opening probability $(p=\beta / \beta+\alpha)$. The pooled estimates of $\alpha$ and $\beta$ obtained from the single-channel current measurements yield a value of 0.34 for $p$, predicting about 2000 functional AChR channels per soma for ciliary ganglion neurons grown in eye medium, and about 700 per soma for neurons grown in $\mathrm{K}^{+}$/eye medium.

Surface labeling of ciliary ganglion neurons with mAb 35 or 
Bgt 3.1, 2 probes believed to recognize AChRs on the neurons (Ravdin and Berg, 1979; Jacob et al., 1984; Smith et al., 1985, 1986; Halvorsen and Berg, 1986; Stollberg et al., 1986), predict on the order of $10^{5}$ sites/neuron. This number is considerably greater than the 2000 functional AChRs per neuron calculated here from physiological studies. Even if it is assumed that 2 $\mathrm{mAbs}$ bind for each receptor, and that half of the receptors are on distal neurites, where they would not contribute to the physiological determination, the number of functional AChRs would still represent only about $10 \%$ of the number of total AChRs on the neurons. That all of the sites recognized by the probes represent AChRs is suggested by Scatchard analysis of the binding, which reveals a class of high-affinity sites with each of the probes (Halvorsen and Berg, 1986; Smith et al., 1986). [In these cases, $\alpha$-bungarotoxin ( $\alpha$-Bgt) is used routinely to block Bgt 3.1 binding to the $\alpha$-Bgt binding component on the neurons (Smith et al., 1983), which would otherwise constitute a second class of sites.] Moreover, the pharmacology and kinetics of Bgt 3.1 binding, in the presence of $\alpha$-Bgt, are consistent with a single class of sites, all representing AChRs (Halvorsen and Berg, 1986), and Bgt 3.1 does specifically and totally block AChR function under these conditions (Ravdin and Berg, 1979). In addition, covalently labeling AChRs on the neurons with a photoaffinity derivative of ${ }^{125}$ I-Bgt 3.1, followed by immunoprecipitation of the solubilized toxin receptor complex demonstrates that Bgt 3.1 and $\mathrm{mAb} 35$ bind to the same component (Halvorsen and Berg, 1987). Finally, the ratio of $\mathrm{mAb} 35$ and Bgt 3.1 binding sites on the neurons remains constant in all culture situations examined, though the total number of sites varies with the growth and regulatory conditions employed (Halvorsen and Berg, 1987). These results make it unlikely that a significant fraction of the sites are unrelated to AChRs. Thus the present experiments suggest that surface $\mathrm{AChRs}$ on ciliary ganglion neurons consist of a small, functional receptor pool and a larger, nonfunctional pool, with members of both pools scoring as AChRs in binding studies with $\mathrm{mAb} 35$ and $\mathrm{Bgt}$ 3.1. There is at present no evidence suggesting the presence of a large pool of nonfunctional AChRs on muscle cells. Precedent does exist, however, for a large reserve of nonfunctional calcium channels from studies in muscle where dihydropyridines are believed to bind specifically to the channels, and yet the number of drug binding sites far exceeds the number of voltage-activatable calcium channels according to biophysical measurements (Schwartz et al., 1985).

Elevated $\mathrm{K}^{+}$concentrations do not reduce the total number of AChRs on ciliary ganglion neurons in cell culture, as measured by either mAb 35 or Bgt 3.1 binding (Smith et al., 1986; Halvorsen and Berg, 1987). This, together with the disparity between the number of AChRs measured by the probes and the number detected physiologically, suggests that only a small fraction of the AChRs on the neurons is functional. Moreover, the neuron can apparently alter the ratio of functional and nonfunctional AChRs on its surface. Recent studies indicate that a cAMP-dependent mechanism can increase the ACh-sensitivity of ciliary ganglion neurons without requiring new AChR synthesis and without increasing the total number of AChRs on the neurons detected by mAb 35 (Margiotta et al., 1987). These results provide support for the hypothesis that neurons can regulate existing AChRs, and further suggest that both functional and nonfunctional AChRs may be present on the neuronal surface. Varying the ratio of functional to nonfunctional transmitter receptors would provide a novel means by which neurons could control their responsiveness to synaptic inputs.

\section{References}

Adams, D. I., and S. Bevan (1985) Some properties of acetylcholine receptors in human cultured myotubes. Proc. R. Soc. Lond. [Biol.] 224: $183-196$.

Anderson, C. R., and C. F. Stevens (1973) Voltage clamp analysis of ACh produced end-plate current fluctuations at frog neuromuscular junction. J. Physiol. (Lond.) 235: 655-691.

Ascher, P., W. A. Large, and II. P. Rang (1979) Studies on the mechanism of action of $\mathrm{ACh}$ antagonists on rat parasympathetic ganglion cells. J. Physiol. (Lond.) 295: 139-170.

Blatz, A. L., and K. L. Magleby (1986) Correcting single channel data for missed events. Biophys. J. 49: 967-980.

Boulter, J., K. Evans, D. Goldman, G. Martin, D. Treco, S. Heinemann, and J. Patrick (1986) Isolation of a cDNA clone coding for a possible neural nicotinic acetylcholine receptor $\alpha$-subunit. Nature 319: 368374.

Brehm, P., R. Kullberg, and F. Moody-Corbett (1984) Properties of non-junctional acetylcholine receptor channels on innervated muscle of Xenopus laevis. J. Physiol. (Lond.) 350: 631-648.

Brenner, H. R., and A. R. Martin (1976) Reduction in acetylcholine sensitivity of axotomized ciliary ganglion cells. J. Physiol. (Lond.) 260: 159-175.

Brett, R. S., J. P. Dilger, P. R. Adams, and B. Lancaster (1986) A method for the rapid exchange of solutions bathing excised membrane patches. Biophys. J. 50: 987-992.

Carbonetto, S. T., D. M. Fambrough, and K. J. Muller (1978) Nonequivalence of $\alpha$-bungarotoxin receptors and acetylcholine receptors in chick sympathetic neurons. Proc. Natl. Acad. Sci. USA 75: 10161020.

Choi, D. W., and G. D. Fischbach (1981) GABA conductance of chick spinal cord and dorsal root ganglion neurons in cell culture. J. Neurophysiol. 45: 605-620.

Colquhoun, D., and A. G. Hawkes (1981) On the stochastic properties of single ion channels. Proc. R. Soc. London. [Biol.] 211: 205-235.

Colquhoun, D., and A. G. Hawkes (1982) On the stochastic properties of single ion channel openings and of clusters of bursts. Phil. Trans. R. Soc. Lond. [Biol.] 300: 1-59.

Colquhoun, D., and B. Sakmann (1985) Fast events in single-channel currents activated by acetylcholine and its analogues at the frog muscle endplate. J. Physiol. (Lond.) 369: 501-557.

Colquhoun, D., and F. J. Sigworth (1983) Fitting and statistical analysis of single channel records. In Single-Channel Recording, B. Sakmann and E. Neher, eds., pp. 191-263, Plenum, New York.

del Castillo, J., and B. Katz (1957) Interaction at endplate receptors between different choline derivatives. Proc. R. Soc. Lond. [Biol.] 146. 369-381.

Derkach, V. A., A. A. Selyanko, and V. I. Skok (1983) Acetylcholineinduced current fluctuations and fast excitatory post-synaptic currents in rabbit sympathetic neurones. J. Physiol. [Lond.] 336: 511-526.

Dichter, M. A., and G. D. Fischbach (1977) The action potential of chick dorsal root ganglion neurons maintained in cell culture. J. Physiol. (Lond.) 267: 281-298.

Dionne, V. E., and M. D. Leibowitz (1982) Acetylcholine receptor kinetics. A description from single-channel currents at snake neuromuscular junctions. Biophys. J. 39: 253-261.

Dionne, V. E., and R. L. Parsons (1981) Characteristics of the acetylcholine-operated channel at twitch and slow fiber neuromuscular junctions of the garter snake. J. Physiol. (Lond.) 310:145-158.

Dionne, V. E., J. H. Steinbach, and C. F. Stevens (1978) An analysis of the dose-response relationship at voltage-clamped frog neuromuscular junctions. J. Physiol. (Lond.) 281: 421-444.

Dreyer, F., K. Peper, and R. Sterz (1978) Determination of doseresponse curves by quantitative iontophoresis at the frog neuromuscular junction. J. Physiol. (Lond.) 281: 395-419.

Dunn, P. M., and L. M. Marshall (1985) Lack of nicotinic supersensitivity in frog sympathetic neurons following denervation. J. Physiol. (Lond.) 363: 211-225.

Fambrough, D. M. (1979) Control of acetylcholine receptors in skeletal muscle. Physiol. Rev. 59: 165-227.

Feltz, A., and A. Trautmann (1982) Desensitization at the frog neuromuscular junction: A biphasic process. J. Physiol. (Lond.) 322:257272.

Fenwick, E. M., A. Marty, and E. Neher (1982) A patch-clamp study 
of bovine chromaffin cells and of their sensitivity to acetylcholine. J. Physiol. (Lond.) 331: 577-597.

Fischbach, G. D., and Y. Lass (1978) A transition temperature for acetylcholine channel conductance in chick myoballs. J. Physiol. (Lond.) 280: 527-536.

Halvorsen, S. W., and D. K. Berg (1986) Identification of a nicotinic acetylcholine receptor on neurons using an $\alpha$-neurotoxin that blocks receptor function. J. Neurosci. 6: 3405-3412.

Halvorsen, S. W., and D. K. Berg (1987) Affinity labeling of neuronal acetylcholine receptor subunits with an $\alpha$-neurotoxin that blocks receptor function. J. Neurosci. 7: 2547-2555.

Hamill, O. P., and B. Sakmann (1981) Multiple conductance states of single acetylcholine receptor channels in embryonic muscle cells. Nature 294: 462-464.

Hamill, O. P., A. Marty, E. Neher, B. Sakmann, and F. J. Sigworth (1981) Improved patch-clamp techniques for high-resolution curtent recording from cells and cell-free membrane patches. Pfluegers Arch. 391: 85-100

Hartzell, H. C., S. W. Kuffler, and D. Yoshikami (1975) Postsynaptic potentiation: Interaction between quanta of acetylcholine at the skeletal neuromuscular synapse. J. Physiol. (Lond.) 251: 427-463.

Jackson, M. B. (1986) Kinetics of unliganded acetylcholine receptor channel gating. Biophys. J. 49: 663-673.

Jackson, M. B., and H. Lecar (1979) Single postsynaptic channel currents in tissue cultured muscle. Nature 282: 863-864.

Jacob, M. H., D. K. Berg, and J. M. Lindstrom (1984) Shared antigenic determinant between the Electrophorus acetylcholine receptor and a synaptic component on chicken ciliary ganglion neurons. Proc. Natl. Acad. Sci. USA 81: 3223-3227.

Katz, B., and R. Miledi (1972) The statistical nature of the acetylcholine potential and its molecular components. J. Physiol. (Lond.) 224: 665-699.

Katz, B., and S. Thesleff (1957) A study of the desensitization produced by acetylcholine at the motor end-plate. J. Physiol. (Lond.) 138: 6080.

Leibowitz, M. D., and V. E. Dionne (1984) Single-channel acetylcholine receptor kinetics. Biophys. J. 45: 153-163.

MacDermott. A. B., and G. L. Westbrook (1986) Early development of voltage-dependent sodium currents in cultured mouse spinal cord neurons. Dev. Biol. 113: 317-326.

Margiotta, J. F., and D. K. Berg (1982) Functional synapses are established between ciliary ganglion neurons in dissociated cell culture. Nature 296: 152-154.

Margiotta, J. F., D. K. Berg, and V. E. Dionne (1985) Regulation of acetylcholine receptors on chick ciliary ganglion neurons in cell culture. Soc. Neurosci. Abstr. 11: 170

Margiotta, J. F., D. K. Berg, and V. E. Dionne (1987) Cyclic AMP regulates the proportion of functional acetylcholine receptors on chick ciliary ganglion neurons. Proc. Natl. Acad. Sci. USA (in press).

McEachern, A. E., J. F. Margiotta, and D. K. Berg (1985) GABA receptors on chick ciliary ganglion neurons in vivo and in cell culture. J. Neurosci. 5: 2690-2695.

Neher, E., and B. Sakmann (1976) Noise analyses of drug induced voltage clamp currents in denervated frog muscle fibers. J. Physiol. (Lond.) 258: 705-729.

Nishi, R., and D. K. Berg (1979) Survival and development of ciliary ganglion neurons grown alone in cell culture. Nature 277: 232-234.

Nishi, R., and D. K. Berg (1981) Two components from eye tissue that differentially stimulate the growth and development of ciliary ganglion neurons in cell culture. J. Neurosci. 1 : 505-513.
Noble, M. D., T. H. Brown, and J. H. Peacock (1978) Regulation of acetylcholine receptor levels by a cholinergic agonist in mouse muscle cell cultures. Proc. Natl. Acad. Sci. USA 75: 3488-3492.

Ogden, D. C., P. T. A. Gray, D. Colquhoun, and H. P. Rang (1984) Kinetics of acetylcholine activated ion channels in chick ciliary ganglion neurons grown in tissue culture. Pfluegers Arch. 400: 44-50.

O'Lague, P. H., D. D. Potter, and E. J. Furshpan (1978) Studies on rat sympathetic neurons developing in cell culture. I. Growth characteristics and electrophysiological properties. Dev. Biol. 67:384 403

Patrick, J., and W. B. Stallcup (1977a) Immunological distinction between acetylcholine receptor and the $\alpha$-bungarotoxin binding component on sympathetic neurons. Proc. Natl. Acad. Sci. USA 74:4689_ 4692.

Patrick, J., and W. B. Stallcup (1977b) $\alpha$-Bungarotoxin binding and cholinergic receptor function on a rat sympathetic nerve line. J. Biol. Chem. 252: 8629-8633.

Rang, H. P. (1981) The characteristics of synaptic currents and responses to acetylcholine of rat submandibular ganglion cells. J. Physiol. (Lond.) 311: 23-55.

Ravdin, P. M., and D. K. Berg (1979) Inhibition of neuronal acetylcholine sensitivity by $\alpha$-toxins from Bungarus multicinctus venom. Proc. Natl. Acad. Sci. USA 76: 2072-2076.

Roux, B., and R. Sauve (1985) A general solution to the time interval omission problem applied to single channel analysis. Biophys. J. 48: $149-158$.

Sakmann, B. (1978) Acetylcholine-induced ionic channcls in rat skcletal muscle. Fed. Proc. 37: 2654-2659.

Sakmann, B., J. Patlak, and E. Neher (1980) Single acetylcholineactivated channels show burst-kinetics in presence of desensitizing concentrations of agonist. Nature 286: 71-73.

Schuetze, S. M., and L. W. Role (1987) Developmental regulation of nicotinic acetylcholine receptors. Annu. Rev. Neurosci. 10: 403-457.

Schwartz, L. M., E. W. McCleskey, and W. Almers (1985) Dihydropyridine receptors in muscle are voltage-dependent but most are not functional calcium channels. Nature 314: 747-751.

Sheridan, R. E., and H. A. Lester (1977) Rates and equilibria at the acetylcholine receptor of Elestrophorus electroplaques. J. Gen. Physiol. 70: 187-219.

Sine, S. M., and J. H. Steinbach (1986) Activation of acetylcholine receptors on clonal mammalian $\mathrm{BC} 3 \mathrm{H}-1$ cells by low concentrations of agonist. J. Physiol. (Lond.) 373: 129-162.

Smith, M. A., J. F. Margiotta, and D. K. Berg (1983) Differential regulation of acetylcholine sensitivity and $\alpha$-bungaroloxin-binding sites on ciliary ganglion neurons in cell culture. J. Neurosci. 3: 23952402.

Smith, M. A., J. Stollberg, D. K. Berg, and J. M. Lindstrom (1985) Characterization of a component in chick ciliary ganglia that crossreacts with monoclonal antibodies to muscle and electric organ acetylcholine receptor. J. Neurosci. 5: 2726-2731.

Smith, M. A. J. F. Margiotta, A. Franco, Jr., J. M. Lindstrom, and D. K. Berg (1986) Cholinergic modulation of an acetylcholine receptorlike antigen on the surface of chick ciliary ganglion neurons in cell culture. J. Neurosci 6: 946-954.

Stollberg, J., P. J. Whiting, J. M. Lindstrom, and D. K. Berg (1986) Functional blockade of neuronal acetylcholine receptors by antisera to a putative receptor from brain. Brain Res. 378: 179-182. 